\title{
KEBIJAKAN PENGHAPUSAN RETRIBUSI PERIKANAN (Analisis Penerapan kebijakan di Kabupaten Pandeglang, Provinsi Banten)
}

\author{
Bayu Vita Indah Yanti dan Maharani Yulisti \\ Peneliti pada Balai Besar Riset Sosial Ekonomi Kelautan dan Perikanan \\ JI. KS. Tubun Petamburan VI Jakarta 10260 \\ Telp. (021) 53650162, Fax. (021)53650159 \\ Diterima 24 Februari 2011 - Disetujui 11 Mei 2011
}

\begin{abstract}
ABSTRAK
Kabupaten Pandeglang merupakan sebuah kabupaten di Provinsi Banten yang memiliki potensi kelautan dan perikanan yang cukup besar. Perolehan pendapatan yang bersumber dari retribusi sektor kelautan dan perikanan merupakan salah satu sumber pendapatan daerah yang cukup besar untuk kabupaten ini. Penghapusan retribusi perikanan merupakan kebijakan yang dikeluarkan Kementerian Kelautan dan Perikanan pada akhir tahun 2009, namun hingga tahun 2010 belum dapat dilaksanakan di kabupaten ini. Tulisan ini menganalisis kebijakan terkait dengan penyebab belum dapat diterapkannya kebijakan nasional penghapusan retribusi tersebut. Berdasarkan hasil analisis memperlihatkan bahwa penerapan kebijakan penghapusan retribusi perikanan di kabupaten Pandeglang sampai saat ini belum dapat dilaksanakan dikarenakan para pihak terkait (stakeholders) menginginkan perubahan kebijakan tersebut secara formal sehingga menimbulkan kepastian hukum dalam pelaksanaannya.
\end{abstract}

Kata kunci: Pandeglang, retribusi perikanan, kebijakan

Retribusi daerah berdasarkan definisi dalam Pasal 1 ayat 64 Undang-undang Nomor 28 Tahun 2009 tentang Pajak Daerah dan Otonomi Daerah, merupakan salah satu pungutan yang dilakukan oleh pemerintah daerah sebagai pembayaran atas jasa atau pemberian izin tertentu yang khusus disediakan dan/atau diberikan oleh Pemerintah Daerah untuk kepentingan orang pribadi atau Badan. Pendapatan yang diperoleh dari retribusi tersebut nantinya akan menjadi salah satu pendapatan asli daerah yang akan dipergunakan untuk membangun daerah.

Kabupaten Pandeglang merupakan salah satu kabupaten hasil pemekaran tahun 2006 di Provinsi Banten. Jika mendengar kata Pandeglang, kita pasti akan mengingat potensi pariwisata (seperti Pantai Carita, Tanjung Lesung, TN. Ujung Kulon). Kabupaten Pandeglang juga dikenal sebagai kota penghasil ikan dan memiliki garis pantai terpanjang di Provinsi Banten $(230 \mathrm{~km})$, sebagai daerah yang memiliki potensi sebagai penghasil ikan, keberadaan tempat pelelangan ikan (TPI) menjadi penting bagi para pelaku usaha perikanan (nelayan, pedagang, pengolah), karena TPI merupakan sarana tempat melakukan transaksi antara nelayan dengan para pembeli (pedagang dan pengolah).

Berdasarkan persepsi dari responden, jasa pelayanan yang diberikan oleh TPI dipandang sebagai sebuah potensi obyek untuk meningkatkan pendapatan asli daerah, berupa retribusi perikanan. Pungutan retribusi yang dilakukan oleh Pemerintah Kabupaten Pandeglang ditetapkan dalam Peraturan Daerah Kabupaten Pandeglang Nomor 12 Tahun 2001 tentang Retribusi Pasar Grosir dan atau Pertokoan yang Diperuntukkan bagi Penyelenggaraan Pelelangan Ikan.

Penerapan pungutan retribusi daerah untuk sektor kelautan dan perikanan menjadi salah satu masalah semenjak lahirnya kebijakan penghapusan berbagai macam bentuk pungutan yang dianggap memberatkan bagi nelayan. Kebijakan yang mulai disosialisasikan pada awal tahun 2010 ini belum dapat dilaksanakan di wilayah Pandeglang ini. Alasan atau penyebab kenapa kebijakan tersebut belum dapat dilaksanakannya akan menjadi permasalahan yang dibahas dalam tulisan ini.

Tulisan ini bertujuan mengungkapkan sejauhmana pelaksanaan kebijakan penghapusan retribusi tersebut di wilayah Pandeglang. Penelitian ini dilakukan dengan menggunakan data sekunder dan data primer (berdasarkan hasil wawancara menggunakan pedoman wawancara dengan responden dan pengamatan). Analisis data penelitian dilakukan secara kualitatif. Lokasi penelitian adalah kabupaten Pandeglang, Banten.

\section{Kerangka Pemikiran Operasional}

KEBIJAKAN PENGHAPUSAN

RETRIBUSI KP (Kebijakan KKP)

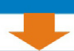

Kebijakan Pemda Provinsi Banten

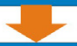

Kebijakan Pemda Kabupaten Pandeglang

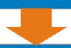

Masyarakat selaku pengguna Jasa TPI

Gambar 1. Kerangka permasalahan retribusi nelayan

Kerangka permasalahan retribusi nelayan yang dibahas dalam tulisan ini merupakan kebijakan penghapusan retribusi bagi nelayan oleh Kementerian Kelautan dan Perikanan, merupakan kebijakan yang 
bertujuan untuk memberikan kemudahan bagi nelayan kecil untuk berusaha sehingga mereka dapat memperoleh pendapatan yang lebih besar dari sebelumnya. Sehingga diharapkan dapat mengurangi jumlah keluarga miskin nelayan. (Gambar 1)

Penerapan kebijakan ini disampaikan kepada Pemerintah Provinsi Banten, namun semenjak pelaksanaan otonomi daerah, kewenangan pemerintah pusat maupun pemerintah provinsi tidak terlalu besar dan hanya bersifat koordinasi. Kebijakan tersebut tetap tergantung dari Pemerintah Kabupaten selaku pemegang kekuasaan daerah otonom Kabupaten Pandeglang. Pemerintah Kabupaten Pandeglang inilah yang nantinya akan berhadapan langsung dengan masyarakat (stakeholders) untuk mengimplementasikan kebijakan tersebut. Gambaran mengenai kerangka analisis pembahasan permasalahan yang diangkat pada awalnya adalah karena keluarnya kebijakan penghapusan retribusi sektor kelautan dan perikanan, terutama yang dilakukan di tempattempat pelelangan ikan, terkait dengan kesejahteraan nelayan. Adanya pungutan (retribusi) yang dikenakan kepada nelayan dianggap sebagai salah satu penyebab berkurangnya pendapatan nelayan dan menyebabkan lahirnya kebijakan penghapusan pungutan tersebut dengan harapan para nelayan meningkat kesejahteraannya. Namun pada implementasinya di masyarakat, tidak serta merta kebijakan penghapusan pungutan tersebut diterima. Berdasarkan data dan hasil analisis pembahasan, selanjutnya kebijakan penghapusan pungutan (retribusi) tersebut di evaluasi untuk kemudian akan diberikan bahan rekomendasi kebijakan sesuai dengan hasil pembahasan dalam penelitian ini. (Gambar 2)
Sejak bulan Juli 2006 Kabupaten Pandeglang dibagi menjadi 35 (tiga puluh lima) kecamatan dan 335 desa/kelurahan. Rata-rata curah hujan selama tahun 2008 berkisar antara 140, 67 mm (Cimanuk) sampai 300,58 mm (Cikeusik).

Responden dalam penelitian ini merupakan informan kunci yang berasal dari instansi-instansi pemerintahan daerah di Kabupaten Pandeglang terkait dengan permasalahan ini, pihak TPI selaku pelaksana pemungut retribusi dari nelayan, dan masyarakat pengguna jasa layanan TPI selaku pihak yang dikenakan pungutan (retribusi). Berdasarkan hasil wawancara dan pengamatan, maka dapat dikemukakan beberapa hal sebagai berikut:

1. Semua responden (100\%) mengakui pentingnya keberadaan TPI selaku tempat transaksi pelelangan hasil penangkapan ikan dari nelayan kepada pembeli.

2. Penghapusan pungutan (retribusi) kepada nelayan disikapi oleh responden jika dari unsur dinas pengelolaan keuangan pendapatan dan aset Kabupaten Pandeglang berpendapat sebaiknya tidak dihapus, karena pendapatan daerah yang berasal dari sektor ini cukup besar ( $\pm 20 \%$ ).

3. Dinas kelautan dan perikanan selaku dinas teknis penghasil pendapatan daerah yang dibebankan target pendapatan asli daerah (PAD) maka sebaiknya pungutan tersebut tidak di hapus. Namun jika sudah tidak dibebankan sebagai dinas teknis, dihapuskannya pungutan tersebut tidak berpengaruh apapun.

4. Pihak TPI berpendapat seperti responden yang berasal dari dinas kelauan dan perikanan, hanya saja karena status kepegawaian mereka yang hanya

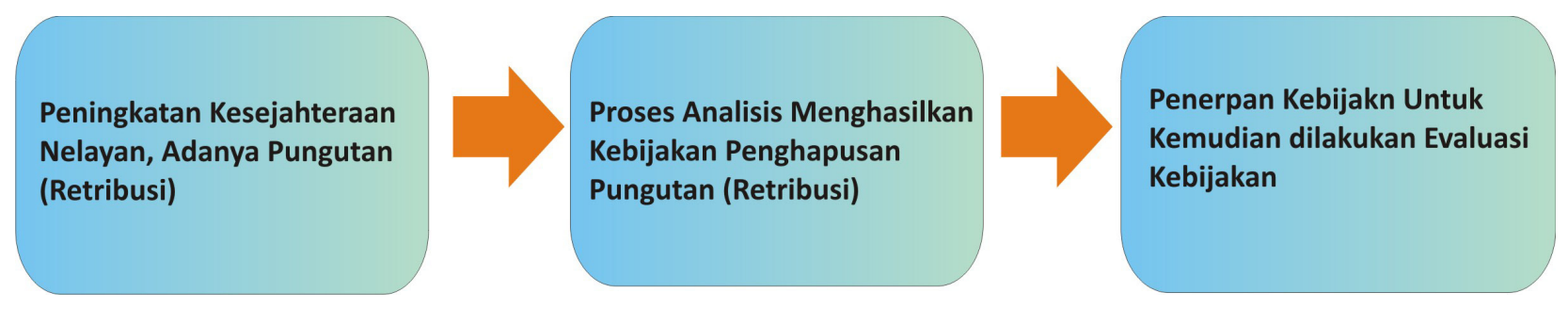

Gambar 2. Kerangka Analisis Pembahasan Permasalahan

\section{Gambaran Umum Wilayah Kabupaten Pandeglang}

Wilayah kabupaten Pandeglang secara geografis terletak antara $6^{\circ} 21^{\prime}-7^{\circ} 90^{\prime}$ Lintang Selatan dan $104^{\circ}$ $48^{\prime}-106^{\circ} 11^{\prime}$ Bujur Timur dengan luas wilayah $2.747 \mathrm{~km}^{2}$ atau sebesar 29, 98\% dari luas wilayah Provinsi Banten. Kabupaten yang berada di ujung barat Provinsi Banten ini mempunyai batas wilayah administrasi di sebelah utara berbatasan dengan Kabupaten Serang, sebelah selatan berbatasan dengan Samudera Indonesia, sebelah Barat berbatasan dengan Selat Sunda, dan sebelah timur berbatasan dengan Kabupaten Lebak. kontrak, mereka berharap setelah penghapusan tersebut dilaksanakan, pemerintah mampu terus mengoperasionalkan TPI dan memberikan penggajian kepada para petugas di TPI.

5. Masyarakat selaku pengguna jasa TPI langsung, tidak berkeberatan adanya pungutan (retribusi) tersebut sepanjang keberadaan TPI tetap ada dan berfungsi sebagaimana mestinya, mereka mengerti pungutan tersebut sebagian dipergunakan untuk membiayai operasional dari TPI dan memang sebaiknya pemungutan dilakukan berdasarkan peraturan resmi 
yang ditetapkan pemda kabupaten Pandeglang ataupun berdasarkan pada kesepakatan antara pengelola TPI dengan para pengguna layanan jasa TPI.

\section{Identifikasi Permasalahan Kebijakan Penghapusan Retribusi}

Kebijakan penghapusan retribusi sektor kelautan dan perikanan lahir pada akhir tahun 2009, kebijakan tersebut dikeluarkan dengan tujuan untuk mengurangi pengeluaran nelayan karena harus membayar retribusi jika memanfaatkan fasilitas jasa pelayanan TPI, sehingga diharapkan nantinya akan dapat lebih meningkatkan pendapatan nelayan. Namun kebijakan tersebut tidak dituangkan dalam bentuk peraturan perundangundangan tertulis, dan hanya dikeluarkan dalam bentuk anjuran dari KKP. Anjuran untuk melaksanakan penghapusan retribusi bagi nelayan di daerah-daerah dilakukan oleh pemerintah pusat, dengan memberikan kompensasi yang dijanjikan akan diberikan dalam bentuk Dana Alokasi Khusus dari Pemerintah Pusat kepada Pemerintah Daerah yang melaksanakan kebijakan tersebut.

Permasalahan terkait retribusi sektor kelautan dan perikanan menurut pemerintah daerah yang teridentifikasi adalah sebagai berikut :

1. Retribusi sektor Kelautan dan Perikanan (KP) merupakan salah satu potensi sumber pemasukan bagi Pendapatan Asli Daerah (PAD) yang cukup potensial, terutama untuk daerah yang memiliki banyak potensi sumberdaya kelautan dan perikanan.

2. Bahwa dasar pemberlakuan Pungutan Retribusi di daerah berdasarkan pada Peraturan daerah yang mengacu pada ketentuan peraturan perundangundangan yang mengatur mengenai retribusi daerah.

3. Bahwa tugas pokok dan fungsi (Tupoksi) dari Dinas KP adalah sebagai Dinas teknis terkait yang masih dibebankan untuk menghasilkan pendapatan dari sektor kelautan dan perikanan.

4. Jika Retribusi sektor KP dihapus, dikhawatirkan tempat pelelangan ikan (TPI) tidak dapat lagi dioperasionalkan, mengingat sumber dana operasional TPI berasal dari Retribusi KP.

5. Jika Retribusi kelautan dan perikanan dihapus, sumber PAD potensial yang cukup besar akan mengurangi jumlah PAD yang diperoleh.

6. Penghapusan Retribusi KP di daerah juga tidak dapat hanya dilakukan dengan surat himbauan biasa, karena pemberlakuan Retribusi adalah berdasarkan pada Peraturan Perundang-undangan (UU, PP, dan Perda terkait dengan retribusi daerah).

Identifikasi permasalahan terkait retribusi KP menurut masyarakat (nelayan, penjual Ikan) menyatakan bahwa :
1. Retribusi KP merupakan salah satu bentuk kompensasi setelah masyarakat mendapatkan manfaat dari TPI;

2. Retribusi KP untuk di TPI selama ini dimanfaatkan utk kepentingan bersama (masyarakat dan Pemda) sesuai dengan yang telah ditetapkan dalam Perda)

3. Jika Retribusi KP dihapuskan, timbul kekhawatiran di masyarakat, TPI tidak dapat lagi memberikan manfaat kepada masyarakat, karena selama ini operasional TPI berasal dari Retribusi KP tersebut.

Jika melihat berdasarkan pada bagan alur peraturan perundang-undangan pada TAP MPR No. III/ MPR/2000 tentang Sumber Hukum dan Tata Urutan Peraturan Perundang-undangan menyatakan bahwa :

Tata urutan peraturan perundang-undangan merupakan pedoman dalam pembuatan aturan hukum di bawahnya. Tata urutan Peraturan perundangundangan RI adalah sebagai berikut :

1. Undang-Undang Dasar 1945;

2. Ketetapan Majelis Permusyawaratan Rakyat Republik Indonesia;

3. Undang-Undang;

4. Peraturan Pemerintah Pengganti Rakyat Republik Indonesia;

5. Peraturan Pemerintah;

6. Keputusan Presiden;

7. Peraturan Daerah;

Jika melihat pada ketentuan TAP MPR yang hingga saat ini belum dicabut, ataupun direvisi, maka peraturan daerah yang menjadi dasar hukum dilakukannya pungutan retribusi tetap berlaku sepanjang tidak bertentangan dengan peraturan perundangan diatasnya (angka 1 s.d 6), karena hingga saat ini UU No. 10 Tahun 2004 tentang pembentukan peraturan perundangundangan tidak juga menyatakan kejelasan kekuatan mengikat dari sebuah peraturan yang tidak lahir sebagai salah satu bentuk peraturan yang tersebut dalam TAP MPR tersebut. Meskipun pada saat ini bukan berarti peraturan-peraturan teknis pelaksana undang-undang yang tidak berbentuk seperti uraian dalam TAP MPR tersebut menjadi tidak berlaku karena ketentuan TAP MPR tersebut. Peraturan-peraturan tersebut tetap berlaku, hanya saja menjadi lebih mengacu pada kebijakan yang diterapkan oleh masing-masing instansi pemerintah daerah (dalam hal terkait dengan pelaksanaan kebijakan pemerintah daerah).

Untuk Kabupaten Pandeglang, pemungutan retribusi dilakukan berdasarkan pada Peraturan Daerah Kabupaten Pandeglang No.12 Tahun 2001 tentang Retribusi Pasar Grosir dan/atau Pertokoan yang Diperuntukkan bagi Penyelenggaraan Pelelangan Ikan yang dibuat berdasarkan pada kewenangan yang diberikan dari undang-undang tentang pajak daerah 
dan retribusi daerah (pada saat ini adalah UU No.28 Tahun 2009) untuk memungut retribusi di daerah. Jika melihat pada materi muatan dari peraturan daerah tersebut, maka pungutan retribusi ini bertujuan untuk meningkatkan pendapatan dan kesejahteraan masyarakat nelayan dengan cara menjual secara lelang semua hasil penangkapan ikan sehingga terjadi pembentukan harga yang dianggap bisa menguntungkan nelayan. Hasil pungutan retribusi tersebut juga tidak $100 \%$ menjadi pemasukan bagi daerah, karena retribusi tersebut juga dipergunakan untuk membiayai operasional TPI dan juga dana bagi nelayan pada saat paceklik.

\section{Penutup: Retribusi Masih Tetap Berjalan}

Setelah mengidentifikasi permasalahan dan pembahasan yang dikemukakan, maka beberapa point penting yang dapat diambil berdasarkan hasil kajian kebijakan penghapusan retribusi di wilayah Kabupaten Pandeglang adalah sebagai berikut:

1. Penerapan kebijakan penghapusan pungutan (retribusi) tidak dapat diterapkan di Kabupaten Pandeglang sepanjang hal tersebut tidak ada peraturan pelaksanaannya (peraturan tertulis), karena pungutan selama ini yang ada menggunakan landasan hukum perda maka jika ingin dicabut pemberlakuannya harus di cabut oleh peraturan yang lebih tinggi atau yang setara dengan peraturan tersebut. Hal tersebut untuk menjamin kepastian hukum di masyarakat.

2. Otonomi daerah memberikan kebebasan bagi pemerintahan daerah kabupaten sebagai pemegang kekuasaan otonom untuk memilih menerapkan atau tidak menerapkan, semua tergantung pada kebijaksanaan pimpinan di daerah.

Rekomendasi kebijakan yang sebaiknya diterapkan untuk keberhasilan kebijakan Penghapusan Retribusi KP adalah sebagai berikut:
1. Sebaiknya penghapusan dilakukan secara formal melalui peraturan perundang-undangan, karena dasar pemberlakuan adalah dengan Perda, maka sebaiknya juga di hapus dengan Perda.

2. Apabila tidak mungkin dilakukan, maka memang tidak ada sanksi yang dapat diterapkan. Karena Pungutan Retribusi dilakukan berdasarkan pada UU No. 28 Th. 2009 tentang Pajak Daerah dan Retribusi Daerah, PP No. 66 Th. 2001 tentang Retribusi Daerah.

3. Pemberlakuan Kebijakan dari Pemerintah Pusat pada era otonomi daerah pada saat ini lebih sulit, karena Pemda menganggap saat ini telah ada Desentralisasi (berdasarkan Paket Perundang-undangan tentang Otonomi Daerah) sehingga jika ada kebijakan yang berpengaruh langsung kepada PAD sebaiknya dilakukan berdasarkan pada Peraturan Perundangundangan yang ada.

\section{Daftar Pustaka}

Anonimous, 2000. Ketetapan Majelis Permusyawaratan Rakyat RI No. III/MPR/2000 tentang Sumber Hukum dan Tata Urutan Peraturan Perundangundangan. http://portal.mahkamahkonstitusi. go.id/eLaw/mg58ufsc89hrsg/11999e0be 8 262450c573df3cf9aa4bcd36a73d8b1.pdf di download pada 30 Maret 2011.

, 2001. Peraturan Daerah Kabupaten Pandeglang Nomor 12 Tahun 2001 tentang Retribusi Pasar Grosir dan atau Pertokoan yang Diperuntukkan Bagi Penyelenggaraan Pelelangan Ikan. LD No. 13 Th. 2001 Seri B.7.

,2004. Undang-Undang Nomor 10 Tahun 2004 tentang Pembentukan Peraturan Perundangundangan. LN No. 53 Tahun 2004 TLN No. 4389.

2009. Undang-Undang Nomor 28 Tahun 2009 tentang Pajak Daerah dan Retribusi Daerah. LN No. 130 Th. 2009 TLN No. 5049. 